\title{
Persecution of the Czech Minority in Ukraine at the Time of the Great Purge ${ }^{1}$
}

\author{
prof. Mečislav BORÁK
}

\begin{abstract}
In its introduction, the study recalls the course of Czech emigration to Ukraine and the formation of the local Czech minority from the mid-19th century until the end of 1930s. Afterwards, it depicts the course of political persecution of the Czechs from the civil war to the mid-1930s and mentions the changes in Soviet national policy. It characterizes the course of the Great Purge in the years 1937-1938 on a national scale and its particularities in Ukraine, describes the genesis of the repressive mechanisms and their activities. In this context, it is focused on the NKVD's national operations and the repression of the Czechs assigned to the Polish NKVD operation in the early spring of 1938. It analyses the illegal executions of more than 660 victims, which was roughly half of all Czechs and Czechoslovak citizens executed for political reasons in the former Soviet Union, both from time and territorial point of view, including the national or social-professional structure of the executed, roughly compared to Moscow. The general conclusions are illustrated on examples of repressive actions and their victims from the Kiev region, especially from Kiev, and Mykolajivka community, not far from the centre of the Vinnycko area, the most famous centre of Czech colonization in eastern Podolia. In detail, it analyses the most repressive action against the Czechs in Ukraine which took place in Zhytomyr where on 28 September 1938, eighty alleged conspirators were shot dead, including seventy-eight Czechs. In this case, fabricated and produced directly in the Zhytomyr Oblast Administration Office of the NKVD, there are clarified the terrorist methods of interrogation and torture of victims, arranged false accusation, which could not been got away, as well as the systematic lying of the authorities on the fate of the victims, which continued after their rehabilitation in 1958, and ended half a century after the executions took place.
\end{abstract}

\section{Keywords}

Czechs and Czechoslovak citizens, Ukraine, political repression, Great Purge

1 The text originated as a preface to compilation of documents Great Purge in Ukraine in 1937-1938. The Czech Dimension, BORÁK, Mečislav - ČERNOUŠEK, Štěpán - KOHUT, Andryj - SERD'JUK, Natalia (Eds.) which is to be published by the Institute for the Study of Totalitarian Regimes in cooperation with the Ukrainian Archive of Security Service SBU in 2018. 


\section{Czech Emigration to the Territory of Today's Ukraine}

Czech emigration to Ukraine has a rich tradition from the days when Ukraine was part of the Russian Empire. The first Czech contacts were rather sporadic and at first associated with the German colonization wave which aimed to the Volga region, mainly due to religious reasons. Mass emigration only started in the second half of the $19^{\text {th }}$ century, mainly due to socio-economic reasons. The offer of Czarist Russia to acquire land and colonize some border territories of the Empire was enticing: the settlers could purchase the land from the owner of a landed estate, or obtain a state land as a hereditary family usance allocation which would become property of the colony. In addition to this agricultural emigration, Czech educators and teachers, shopkeepers, musicians, brewers, millers, gardeners and others went to larger towns. At the end of the 19th century, over fifty thousand people registered under Czech and Slovak nationalities in the census while the vast majority of Czechs had settled mainly in Ukraine. ${ }^{2}$

The first group of exiles from Eastern Bohemia went to the Poltava and Taurid governorate which included Crimea where they established several Czech settlements - Bohemka (now Lohanovo), Tábor (Makarivka), Carekvič (Pushkino) and Alexandrovka; a known settlement outside of Crimea was Čechohrad (Novhorodkivka). Descendants of the Czech religious exiles from Prussian Silesia (around Zelowa) came to the Kherson governorate, and many settled in Odessa. The largest group of emigrants, however, came to the Volhynia governorate which bordered on the Austrian Halič. They proved themselves there as good farmers - they introduced more modern methods of tillage and cultivation of better varieties of cereals, potatoes, fruit and hops, which allowed the emergence of food making and processing businesses, particularly breweries and mills but also agricultural machinery factories. By the end of the $19^{\text {th }}$ century, twenty-seven thousand Czechs lived in Volhynia, and over seven and a half thousand of Czechs had settled in the near Kiev governorate (e.g. in the village Zubovština). Kiev became the centre of Czech social life for the Kiev, Volhynia and Podolia governorates where many Czech entrepreneurs and traders had settled, but also representatives of the intelligentsia and skilled workers. They founded the Czech-Slavic Meeting, the J. A. Comenius Czech Educational Association, and published the magazines Ruský Čech (Russian Bohemia) and Čechoslovan (Czech-Slav). ${ }^{3}$

The tsarist authorities provided good existential conditions but they also suddenly started forcing them to accept Orthodoxy and the Russian Empire nationality. At the beginning of the First World War, the majority of Czechs had accepted both the Russian nationality and Orthodoxy, which especially applies to the community of Volhynian Czechs. The Czechs who had come here not long before the war were considered as Austrian citizens, nationals of an enemy state; the tsarist regulations on deportation and seizure of property released in the first days of the war applied to them. Therefore, they sought to obtain Russian citizenship and sometimes accepted orthodoxy as well. ${ }^{4}$ The tsarist imperial authorities

2 VALÁŠKOVÁ, Nad'a: Češi v Rusku [Czechs in Russia.], in: Češi v cizině [Czechs Abroad], 9, 1996, 33.

3 VACULíK, Jaroslav: České menšiny v Evropě a ve světě [Czech Minorities in Europe and in the World], Prague 2009, 218-220.

4 VACULíK, Jaroslav: Dějiny volyňských Čechů Díl II. (1914-1945) [History of Volhynian Czechs Part II. (19141945)], Prague 1998, 5-6. 
approved a proposal from the Czech community on the creation of the Czech Company, the voluntary military units within the Russian army, driven also by the effort to support the Austrian-Hungarian Czechs and Slovaks' hopes of statehood. Later, Czech and Slovak prisoners of war joined the local Czechs, gradually forming another large group of our compatriots in Russia who supported the leadership of Czechoslovak exile in the West. After the battle of Zborov, Russian authorities agreed with the prisoners entering the Czechoslovak army. They were to fight on the side of the Entente on the Western front, but due to the evolution of the war and the post-war circumstances, they were transported to their homeland via Siberia and Vladivostok.

Many prisoners were involved in the life of Czech colonies and settled in them, others stayed here for various reasons (due to illness, marriage, job opportunities, the opportunity to acquire property, the desire for adventure, political aspirations, etc.), and they became members of the Czech minority. Some retained Austrian citizenship, others acquired the Czechoslovak citizenship and later mostly accepted the Soviet citizenship, as they were forced to it at the end of the 1930s. In contrast, about ten thousand Czech countrymen returned back to their homeland, mostly in fear of civil war, famine and the Bolshevik regime. The compatriots who had stayed were provided material assistance and a credit program worth of fifteen million Czechoslovak Crowns which allowed the Czech colonists a five-year interest-free loan for the purchase of farm machinery and seed. This help was taken advantage of by Czech farmers especially in Ukraine, and by introducing agricultural machinery, they increased the prosperity of their farms. ${ }^{5}$ Later, however, the credit assistance paradoxically contributed to the harsh persecution of Czech settlers, because they were marked as kulaks precisely due to their farming.

After the First World War, Russia lost its western provinces, mainly in favour of Poland and Romania where there were allegedly about thirty thousand Czechs and Slovaks. At the first census in the Soviet Union in 1926, it was established that over twenty-seven thousand Czechs and Slovaks lived there, and the same number of them stayed here during the census in 1939. Most of them lived on the territory of Soviet Ukraine - over sixteen thousand, about seven thousand of whom in Volhynia; according to the Census of 1921, about twenty-five thousand Czechs lived in the Polish part of Volhynia. ${ }^{6}$ The Division of the Volhynia governorate by the Riga peace of 18 March 1921 between the USSR and Poland made the Czechs in eastern Volhynia strictly separated from their neighbours in Poland, which affected many families, and throughout the inter-war period, they shared a common destiny together with the other inhabitants of the land of the Soviets, including political repression. Their position after the breakdown of the world war and of the civil war temporarily changed for the better when the so-called. New economic policy was introduced, allowing farmers private farming and the sale of surpluses. Also, the aforementioned credit program helped them so the Czech settlements belonged to the richest ones in Ukraine. There was an extension of the rights of national minorities and by the end of the 1920s,

5 ŠEDIVÝ, Ivan: Sdružení Čechů a Slováků z Ruska a československá vláda 1919-1929 (Podpory, subvence, dotace, odškodněni) [Association of Czechs and Slovaks from Russia and the Czechoslovak Government 19191929 (Aids, Grants, Subsidies, Compensation)], in: Československý časopis historický [Czechoslovak Historical Magazine], 36, 1988, 2, 212-237.

6 VACULÍK, Dějiny volyňských ..., 32, 81, 82. 
the Czechs already had their national councils in thirteen municipalities, organized cultural and awareness-raising activities, including amateur theatres, and they had nineteen Czech schools. ${ }^{7}$

In the early 1920s, it was assumed that after the settlement of political relations, it would be possible to build on the earlier Czech commercial and entrepreneurial activities. ${ }^{8}$ The economic difficulties had forced the Soviet Government to find ways to bring qualified professionals of various industries into the country. Soviet authorities tried to attract also agricultural and industrial immigrants to the USSR, promising them advantageous working conditions. The newly-established agricultural and industrial enterprises had to submit to Soviet laws and comply with the collective form of management. However, the idea of building cooperative farms did not result in lack of confidence as it followed European tradition, which is why many volunteers streamed into communes and immigrant cooperatives from Western countries, including Czechoslovakia. Ukraine, however, was not directly affected by the creation of Czechoslovak communes and cooperatives as transports with the colonists continued deeper into the inland. In contrast, however, in the Donbass industrial area, many Czechoslovak experts and skilled workers had settled whose experience was demanded extraordinarily. Also, many former members of the Czechoslovak communes which were no longer in existence found work here.

Successful Czech entrepreneurs and farmers soon had to pay for their success and for their illusions heavily, as they were labelled as exploiters and kulaks, and in addition, as suspicious foreigners or former legionaries, they were considered as clear opponents of the Soviet regime and they did not have any escape from the repression campaigns. Since the 1930s, violent, forced collectivization had been destroying relations in the countryside, causing the demise of individual farming and turning prosperous farmers into class enemies who were subject to harsh repression. In minority politics, a combat against the alleged bourgeois nationalism of non-Russian nationalities started, which eventually led to the demise of minor nationality education. The political persecution of all persons and groups the regime arbitrarily declared as anti-Soviet elements was becoming severer. It particularly heavily affected also the Czech community during the period of the Great Purge of 1936-1938.

After the fall of the Czechoslovak Republic and the war division of Poland in 1939 there was a fundamental change in both the nature and extent of the Czechoslovak emigration to the USSR. Economic emigration had ceased almost entirely and political emigration only consisted of a marginal portion of Communists while refugees fleeing the terror of German and Hungarian invaders (from the Czech lands and Carpathian Ruthenia) prevailed. Some Czech groups did not find themselves in the USSR of their own will but due to Soviet expansion westward, as members of the traditional Czech minorities on the territory of Poland and Romania (which included in particularly numerous Czechs in Volhynia and lesser communities in Bukovina and Bessarabia), the soldiers of the Svoboda legion captured while retreating from Poland, or Jews driven out by the Nazis from the camp of Nisko over San and Bug to the USSR. ${ }^{9}$

7 Ibidem, 85, 90, 93.

8 VALÁŠKOVÁ, 38, 45.

9 See also e.g. BORÁK, Mečislav: České stopy v Gulagu. Z výzkumu perzekuce Čechů a občanů ČR v Sovětském 


\section{First Political Persecution of the Czechs}

The fate of the Czechs in Ukraine was tragically affected by the civil war years, especially the white and the red terror sprees in the first years after the Great War, when Ukraine became the battlefield of absolutely conflicting political interests. The arrival of the Bolsheviks to Volhynia in May 1919 led the countrymen to even apply for protection by the Czechoslovak Government, while the well-to-do fled to Poland and the Czech Republic. Repression against the inhabitants who were considered as opposition to the Bolsheviks was organized by the Special All-Ukrainian Commission for the Fight Against Contrarevolution and Sabotage (Vseukrajinskaja črezvyčajnaja komissija, VČK, also abbreviated as Cheka, ČK). Several Czech leaders were shot dead in the red terror (e.g. J. A. Somol from Mirohoště, Šneidr from Dubno), seventeen Czechs were executed by decision of the Kiev Cheka for alleged counter-revolutionary activities and sabotage. ${ }^{10}$ These included for example Joseph Ma ek from Kiev, the secretary of the administration of the Union of Czechoslovak Associations in Ruthenia, Jan Volf, the accountant Jan Kratochvíl, the clerk Jan Protiva, the doctor Oldrich Dvorák and the telegraph operator Řehoř Chorvat. The threat of persecution also loomed over the members of the Czechoslovak legions, whether they came from the ranks of the local Czechs, or they were prisoners of war who had settled in Ukraine after the war (for example, Jiří Komárek was executed for "voluntary service in the Czechoslovak Corps" in 1920). Even in the early 1920s, the brewer Boleslav Homolka from Odessa, miller technician Jindřich Hřibský from Lviv, and fire technician František Rohlena from Zhytomyr were shot dead for political reasons. ${ }^{11}$

The first cases of mass persecution appeared in Volhynia already in 1925 in the process with Czech long-time residents in Kiev which were followed by the process against two Czech teachers from Alexandrovka and Bohemka in 1927. The repression in the late 1920s were directed against farmers who refused to enter into collective farms which was considered as anti-Soviet campaigning. Any pretext could serve retaliation, including fabricated membership in counter-revolutionary organizations. In February 1928, eleven members of the Czech agricultural association "Cooperative" ("Družstvo"), founded at the end of 1923 to provide assistance to Czech colonists living in the USSR, were arrested. The members of the association middled agricultural machines which were delivered from Czechoslovakia to the Soviet Union. In Volhynia, the "Cooperative" worked in the Czech colonies of Czech Kroshnia in the Zhytomyr district, and in Okilok, Czech Vysoko and Churanda-Vynohrady in the Cherniachivsk district and in the town of Cherniachiv. The arrested were accused of conducting anti-Soviet campaign under the veil of commercial activity, maintaining contacts with the Czech Consulate and handing over messages of economic character to V. J. Čermák, the envoy for agricultural loans at the Czechoslovak diplomatic seat in Moscow, and to professor E. A. Rychlík, the well-known scientists in the field of ethnography, who was

svazu [Tracing Czechs in the Gulag. From the Research on the Persecution of Czechoslovak Citizens in the Soviet Union], Opava 2003, 58-101.

10 VACULÍK, Dějiny volyňských ..., 9.

11 BORÁK, Mečislav: Zatajené popravy. Češi a českoslovenští občané popravení na sovětské Ukrajině: z historie Velkého teroru na Volyni a v Podolí. [Secret Executions. The Czechs and the Czechoslovak Citizens Executed in the Soviet Ukraine: a History of the Great Purge in Volhynia and Podolia], Opava 2014, 37-39. 
labelled as an agent of the Czechoslovak foreign intelligence. Because the accusation did not provide compelling evidence in order for trial to be held, the then-security-apparatus decided within the bounds of its powers: The Special Council of the College of the State Political Directorate (GPU) of the USSR exiled most of the accused "socially hazardous kulak elements" to Siberia for three years and rid them of the right of residence in some areas of the USSR. ${ }^{12}$

Probably most tragically, the the Czech minority was affected by the campaign against kulaks, accompanied by violence and repression. For the Czech farmers, collectivization meant destruction of the results of their lifetime and sometimes multi-generational efforts to create and bring to prosperity their estates for which they left their home country for abroad. Collectivization did not correspond with the traditional practices of Czech farmers which is why it inflicted extraordinary suffering on them. It rid them all property and economic superiority that ensured their safety from their environment and protected them from the threat of assimilation. Collectivization was accompanied by foreclosures, displacement of rich farmers along with their families to neighbouring counties as well as to remote northern and eastern areas of the USSR; some of the kulaks were shot. The "dekulakized" property of the displaced persons was officially awarded to Russian re-settlers. Some of the Czech residents attempted to escape the persecution by leaving for Czechoslovakia, others preferred going into the Russian inland to work in the industry. Applications of Czech colonists for the issue of Czechoslovak passport and for permits to travel outside the USSR, which the Soviet authorities considered as manifestation of hostility. ${ }^{13}$ In 1930, for example, the families of Czech farmers from Krushinetz, Ivanovich, Okolek, Kroshna and other villages were deported to Siberia for forced labour. Report from the Czechoslovak Ambassy in Moscow from February 1931 mentions mass displacement of Czech colonists from the Ukraine, especially from the area of Volhynia, to the vicinity of Arkhangelsk and central Siberia, where they are forced to hard forest and wood-processing labour. ${ }^{14}$ According to the estimate of Vladimír Hostička, over two thousand Volhynian Czechs were affected by the repression. ${ }^{15}$ The Czech minority in Ukraine was also hit hard by the events associated with the famine caused by the forced collectivization which decimated the local population.

The persecution, however, did not only involve farmers at that time. In 1928, for example, the whole Czech theatrical club in Kroshno were arrested and most of its members did not return from the camps. In 1930, sixteen members of an amateur theatrical club in Selenchina were sentenced. ${ }^{16}$ After the Congress of Czech teachers in Zhytomyr in the summer of 1930, a number of them were arrested and accused of spying for Czechoslovakia and France, of anti-Soviet activity, campaigning against the Soviet Government and of religious

12 Ibidem, 39-40.

13 VALÁŠKOVÁ, 45; VACULíK, České menšiny ..., 221-222.

14 URBAN, Rudolf: Na Sibiřr? Zkušenosti českých osadníků v zemi sovětů [To Siberia? Experience of Czech Settlers in the Land of the Soviets], Prague 1943, 32-36.

15 HOSTIČKA, Vladimír: Volyňští Češi a jejich perzekuce v SSSR [Volhynian Czechs and their persecution in the Soviet Union], in: Střední a východní Evropa v krizi XX. století [Central and Eastern Europe in the crisis of the twentieth century], Prague 1998, 50.

16 VACULík, Dějiny volyňských ..., 95-96. 
campaigning. Other representatives of the Czech community in Ukraine joined them from August to December 1930. The personnel of the NKVD (People's Commissariat for Internal Affairs) then selected a total of thirty-seven people from among them who were suitable for further use in artificial creation of anti-state groups. Thus, the never-existent "espionagediversionary and counter-revolutionary organization of the Czech General Staff" was fabricated. The final charge of this group was even printed in a special booklet which was used by the NKVD investigators in the whole of Ukraine as a model for creating similar enemy groups. ${ }^{17}$ The persons referred to in the file were tried as part of the Kharkiv "teacher trial", and the alleged head of the organization, Jaroslav Štrombach, as a high-ranking officer (commander of the $44^{\text {th }}$ firing division of the Zhytomyr company) was used by investigators for all-Ukrainian plans of conspiracy as part of operation "Vesna" and sentenced to death penalty by the College of the GPU in Kharkiv in May 1931. The process before the Supreme Court in Kharkiv, held on 12-14 June 1931 in the building of the OGPU, eventually covered only twenty-one people, when the twelve Czech teachers were supplemented by nine other Czechs, officials of the Bohemian movement. Without the possibility of defence or of getting acquainted with the accusation, they were charged as a group of spies and diversionists, preparing the break-up of the USSR, diversion, assassinations and counterrevolutionary youth groups, which should prevent collectivization. The court pronounced ten death sentences and eleven sentences of heavy imprisonment. The convicts were eventually dispatched to the infamous Gulag at Solovetsky Islands where in 1935, all the death-row prisoners' sentences were amnestied in the form of change to ten years of imprisonment in the Gulag. ${ }^{18}$ Some of them were later released, but at the time of the Great Purge, they were arrested again and shot. Another example of repression was the shooting of three members of the leadership of the kolkhoz Pioneer in Cechohrad in the Melitopol district (including the chair of the kolkhoz, František Laurel) in 1933, who were accused of mismanagement of the kolkhoz and errors in implementing collectivization. ${ }^{19}$ The relationship of the Soviet authorities to national minorities, originally quite amiable, began to gradually change and suspicion of the minorities as foreign elements in society outweigh in it. The former policy of "rooting" (korenizacija), the appointment of core groups from local resources, was very helpful to minorities, because they supported their ethnic, cultural, and economic development. They were to get ethnic minorities to support the Soviet regime, however, the promotion of national languages to the detriment of the Russian language was met with lack of understanding and even open resistance by the Russian speaking population, and later also in the ranks of the Communist Party. At the

17 ŠEVČUK, Jurij: Polityčni represiji proty českoji intelihenciji Žytomyrščyny $v$ dobu "Velykoho teroru", in: Istoryko-heohrafični doslidžennja v Ukrajini, Instytut istoriji Ukraine 2009, 11, 241-247; Haluzevyj deržavnyj Archive Services bezpeky Ukraine [Departmental State Archive of the Security Service of Ukraine; hereinafter referred to as HDA SBU], f. 6, spr. 57288-fp., T. 2, Obvinitělnoje zaključenije po dělu špionsko-diversijnoj i kontrrevoljucionnoj organizacii razvedki češskogo generalnogo štaba. Po obviněniju: Štrombacha Ja. A., Vodsedaleka A. A., Jakovleva V. Z., Bezděka Ju. I.. Rychlika Je. A. i dr. Kharkov, GPU, 1931.

18 The best description of the process was given by DVOŘÁK, Jan: Antonín Vodsedálek a proces s českými učiteli na Ukrajině [Antonín Vodsedálek and the Process with Czech Teachers in Ukraine], in: Pamět' a dějiny, Revue pro studium totalitních režimů [Memory and history. Revue for the Study of Totalitarian Regimes], 7, 2013, 4, 97-108.

19 BORÁK, Zatajené popravy, 43, 46. 
beginning of 1930s, this process was completely stopped and its followers were subject to repression. Moving away from the political course of the country focused on the revival of the national and cultural specificities was then met with manifestations of espionage mania and search for internal and external enemies. It significantly affected especially the border area, populated by different nationalities. ${ }^{20}$

\section{The Great Purge in 1937-1938 and Its Czech Specificities}

Repression of the period of the Great Purge differed significantly from the repression of the previous years: while previously, the criminal authorities dealt mainly with "nonproletarian elements" (kulaks, businessmen of the time of the NEP, members of the "old" intelligentsia), the spear of repressions now turned against the representatives of other social groups. The main objectives now were the annihilation of the rest of the political opposition, a purge of the party and state apparatus (and the creation of a new, absolutely devote Stalinist leadership), the total destruction of the remnants of the exploiting class (landowners, kulaks, the bourgeoisie, the participants in the armed struggle against the Soviet power), and the suppression of even the slightest signs of free thought in all layers of society. The Stalinist regime also referred to the threat of war, and the need to annihilate the "fifth column" of the enemies within the country. Also, culprits of the economic difficulties in the development of socialism were sought so that they could be blamed. In Ukraine, mass repression bore its specific nature, as here, there was a clear national focus. Allegations of Ukrainian nationalism, chauvinism, of the nationalist deviations, of membership in nationalist counter-revolutionary organizations, these were very common "crimes" in the falsified and fabricated investigative files of the accused persons. ${ }^{21}$

Some kinds of repression in Ukraine preceded the later mass nationality-based operations of the NKVD. For example, in October 1935, the Politburo of the Central Committee of the Communist Party of Ukraine and in November also the Central Committee of the All-Union Communist Party approved the proposal of the Vinnytsya Oblast Committe of the party for the displacement of 1,500 Polish families from the "frontier districts" on the grounds that the Polish population is "unreliable", suspected of spying and mostly belongs to "actively religious and other contra-revolutionary elements".22

A later implementation of this measure included in many cases also the families of Czech colonists. At the turn of the years 1936 and 1937, the Central Committee of the Communist Party of Ukraine (Bolsheviks) were accused of Trotskyism, Ukrainian nationalism and the "right deviation" and the entire leadership of the party was exchanged. New officials then launched a purging campaign and prepared repression even in the managing structures. ${ }^{23}$ A major impulse for the systematic development of the elimination operations of the Great Purge was given by the resolution of the Politburo of the Central Committee of the AllUnion Communist Party of 2 July 1937 "On Anti-Soviet Elements". This telegram to the

20 lbidem, 44.

21 Polityčni represiji na Vinnyččyni. 1918-1980-ti roky, in: Reabilitovani istorijeju. Vinnycka oblast, 1, Vinnycja $2006,43$.

22 lbidem, 43.

23 lbidem, 44. 
the party leadership of the republics, regions and oblasts ordered to focus the repression on the kulaks who had returned home after years of imprisonment in the Gulag and from exile, and "immediately shoot" those of them who display animosity. For the administrative execution of the command, the so-called "troikas" ("threes") of the NKVD were to be summoned again and the number of persons intended to be shot or deported to Gulag was to be established in each administrative unit. On the same day, a telegram containing the instructions on the execution of the operation came from the people's Commissioner of the Interior of the USSR, M. Yezhov. The chiefs of the NKVD, the state police and militia had two days to examine all of its investigative and agency material on criminal and kulak elements and determine the persons intended for execution or imprisonment in the Gulag. The produced supporting documents contained the details of the place of residence of persons intended to arrest, on the composition of their families, the personal characteristics of the Municipal Council and of the cooperative, on social status and financial circumstances, confirmation of judicial and administrative organs of the state of health and the registration of personal residence, the witness testimony protocols and the communication of Agency authorities, and the consent of the Prosecutor to arrest. ${ }^{24}$

The main role in organizing the mass arrests was carried out by inter-district operative groups of the police, formed in the former sightseeing centres and large resorts. On the territory of the Republic, forty-five such inter-district operational GUGB NKVD groups were formed in Ukraine. Officials of Oblast Administrations and District Departments of the NKVD were appointed as their heads. They took the arrested to prisons or kept them in custody on the premises of the NKVD, the arrests had to be confirmed by the Group's Chief and the District Attorney. Also active members of the Central Committee of the Communist Party of Ukraine took part in the operation. To prevent evasions of Ukraine, the degree of border protection was increased before the beginning of the operation. ${ }^{25}$

The repressive activities of extra-judicial "threes" ("troika") and "twos" ("dvoika"), which had largely been kept secret before the public, were in part complemented by the judicial authorities, who on the contrary were completely directed to the public, even holding public trials. Their aim was to cover up the true cause of the economic problems and channel public anger at the alleged specific culprits, labelled as enemies and saboteurs. In Ukraine only in the period from 1 June 1937 to 10 January 1938, seventy-two public trials were held during which a total of 238 of the 399 convicts were sentenced to execution by shooting. ${ }^{26}$

A meeting of the heads of NKVD in January 1938 summarised the hitherto performance of the "mass operations" and expressed itself for an extension of the activities of "troikas" and of the mass operations. In February 1938, Yezhov, asked the President of the Council of People's Commissioners, Molotov, to increase the already allocated subsidy of twentytwo million rubles on the implementation of the operations to seventy million rubles, especially due to deportation of kulaks and anti-Soviet elements. Thus, the planned costs

24 PODKUR, Roman: "Velykyj teror" na Vinnyččyni (1937-1938 rr.): dijalnist' terytorialnogo aparatu organiv deržavnoji bezpeky, stereotypy svitogljadu čekistiv, in: Zločyny totalitarnych režimiv v Ukrajini: naukovyj ta osvitnij pogljad, Kiev 2012, 61-63; Polityčni represiji na Vinnyččyni, 45-46.

25 PODKUR, 63.

26 Polityčni represiji na Vinnyččyni, 54. 
for the execution of repressions increased more than threefold. ${ }^{27}$ The evaluation showed that Ukraine fulfils the limits of repression too sluggishly and Stalin decided to send Nikita Khrushchev as first Secretary of the new party to Kiev. At the same time, Moscow approved an additional limit on shooting down another six thousand people for Ukraine, and the operation of "troikas" was extended. ${ }^{28}$

In mid-February, 1938, Nikolai Yezhov arrived in Kiev on a special mission to impart that the repression not only will continue, but also that it must intensify. The local representatives were to submit supplementary requests for additional limits (by 16 February, these requisitions to the limits for the oblast "troikas" that came from the regional administrations of the NKVD suggested repression of 46,150 people, of which category I. designated for shooting counted "only" 23,650 people). However, at an operational meeting on 17 February, Yezhov said, there is a need in Ukraine to shoot another thirty thousand enemies, and this was confirmed by the Politburo of the Central Committee of the All-Union Communist Party the same day. Yezhov expressed dissatisfaction with the results of the repressions in Ukraine. He in particular criticized the fact that Ukraine had not kept records of the enemies of the regime properly so the repressive operations were inefficiently effective. Therefore, the next phase of the operation was to take place on a completely new basis. ${ }^{29}$

After Yezhov's departure, the inspection of the operational brigade of the Main Administration of State security of the NKVD of the USSR started working in Kiev. The audit was officially to summarise the results of the work in the detection of "espionageTrockyist, right-wing, military-fascist, nationalist and other anti-Soviet forces" in Ukraine. The inspectors criticised the disorderly registers, low level of investigation, intermittent arrest campaigns (such as the inclusion of all ten thousand people recently excluded from the Communist Party of Ukraine) among the persons intended for repression. Operation possibilities were not used in the search for enemies, attention should be rather paid to transportation and the specificities of the border region. Operational groups were to be deployed to the Oblast Administrations of the NKVD and immediately begin searching enemies of the regime. ${ }^{30}$

That's when performing a special operation focused on the Czech minority in Ukraine was to be first considered. The hitherto national operations of the NKVD primarily hit Germans, Poles, Latvians, Estonians, Finns, Greeks, Romanians and many Asian Nations, according to the specific national situation in individual regions of the USSR. Many Czechs were persecuted in these operations, especially in connection with the Germans and the Poles, but a separate operation against them had not been officially announced because with the exception of a few Ukrainian districts, their communities were not numerous. However, a proposal of the people's Commissioner of the Interior, M. U. Yezhov from the turn of

27 RAFALSKA, Tetjana L.: "Velykyj teror" na Žytomyrščyni (lipec 1937 r. - listopad 1938 r.), Disertacija, Kiev, Nacionalnyj pedagogičnyj universytet M. P, Dragomanova 2010, 129.

28 ŠAPOVAL, Yuri I.: "Ukrainskije nacionalisty" v ramkach prikaza na primere Kijevskoj oblasti, in: Stalinizm v sovetskoj provincii. 1937-1938 gg. Massovaja operacija na osnove prikaza, 00447, Moscow 2009, 392; ŠAPOVAL, Yuri I. - PRYSTAJKO, Volodymyr I. - ZOLOTAROV, Vadym A.: ČK-DPU-NKVS na Ukrajini. Osoby, fakty, dokumenty, Kiev 1997, 501-502.

29 ŠAPOVAL: "Ukrainskije nacionalisty", 393; RAFALSKA: "Velykyj teror", 132-133.

30 ŠAPOVAL: "Ukrainskije nacionalisty", 393; RAFALSKA: "Velykyj teror", 134-136. 
February and March, 1938 has been preserved, "On the shortcomings of the preparation and implementation of mass operations in Ukraine" where the necessary measures to remedy included:

"3. Perform in a sufficient manner a special operation against the Czechs in the USSR, with discussion of cases within the command no 00485. The arrest shall be subject to the following categories: a) persons associated with the Czech diplomatic offices, situated in the territory of Ukraine; b) former Czech Legionnaires; c), anti-Soviet, Czech nationalist activists in Czech colonies connected with foreign countries; d) kulaks and the clergy of the Czech colonies; e) political emigrants from Czechoslovakia, except for people proven and trusted." 31

Thus, the command assigned to add the Czechs to the national operation of the NKVD against the Poles, declared already in August 1937. This soon became manifest through the increase of accusations of Czech settlers of the membership in the underground Polish military organization (Polska Organizacja Wojskowa, POW) or of espionage in favour of Poland. At the same time, however, there were more and more often own-initiative attempts by the investigators of the NKVD to construct purely Czech espionage, sabotage, and other diversionary counter-revolutionary organizations according to specific conditions in each of the centres of the Czech minority in Ukraine. It meant a significant intensification of the repression against the Czechs which only came at a time when the intensity of the Great Purge was already weakening. While elsewhere in the USSR terror was at its height in 1937, in the Ukraine, it was on the contrary and it only intensified after the aforementioned criticism of Moscow Headquarters. According to the findings, at least 181 Czechs were shot in 1937 in Ukraine and in 1938 at least 352 of Czechs, twice as many as in the first period of terror. It testifies well of the true nature of the "executions", hastily performed on political order. Many of them were carried out in the autumn of 1938, when the terror was about to be stopped and the search for culprits who would be blamed for the responsibility for the illegal "mistakes" was starting.

Researches have so far proved over 660 Czechs executed by the Soviet regime in Ukraine due to political reasons which is roughly half of all Czechs and Czechoslovak citizens executed in the former Soviet Union. For the Czechs, Ukraine was clearly the worst scene of political repression. Compared to Moscow which was the centre of the whole State, and thus quite a significant number of the executed Czechs and Czechoslovaks came from there (over 120 people), the Ukrainian executed are remarkably different at first glance: instead of Moscow's elite and members of the intelligentsia, it was clearly simple farmers and workers who were mostly among the victims in Ukraine, while according to the class principles of the communist doctrine, they should have been the masters of their country. They were killed by a monstrous social system they naively believed to provide a fair place to live to them.

Already a brief analysis of the structure of the executed people showed that nearly a third of them (200 people) came from the territory of former Czechoslovakia, mainly from the

31 Velykyj teror na Ukrajini. "Kurkulskaja operacija" 1937-1938 rr. Častyna II, KOKIN Sergij - JUNGE, Mark (Ed.), Kiev 2010, 31; MOZOCHIN, Oleg B.: Pravo na represssii. Vněsuděbnyje polnomočija organov gosudarstvennoj bezopasnosti. Statističeskije sveděnija o dějatělnosti VČK-OGPU-NKVD-MGB SSSR (1918-1953), 2-e izd, Moscow 2011, 191-192. 
Czech lands; for example, there were eighteen from Prague. The actual number of natives of the "old country" may be even higher, as we do not know the birthplace of fifty-four other persons. The political terror fell heavily on the whole of Czech colonies, especially on Volhynia. According to place of birth, forty-two Czech natives from Czech Kroshnia, twelve from Vilshanka, twelve from Mykolaivka, twelve from Antonivka, ten from Vysoké. And it did not involve only Volhynia, for example, seventeen Czech victims came from Čechohrad in Zaporizhzhya. The actual number of victims from those communities will be even higher, as there also lived Czechs who were born elsewhere. Only five people came from Slovakia, but not all of them subscribed to Slovak nationality. By nationality, there were in addition to the prevailing Czechs also at least sixteen Germans among the victims, mostly from the border regions of the Czech lands, seven Ukrainians, four Poles and two Hungarians.

According to the place of execution, victims shot in Zhytomyr prevail and there were at least 176; followed by Kiev as administrative centre of the country, where sixty-eight were shot. Many victims were also in the larger cities and industrial centres, for example. Sixtyfive people in Dnipropetrovsk (along with Dniprodzerzhynsk), thirty-nine people in Kharkiv, thirty-seven people in Kamyanets-Podilskyi, thirty-three people in Donetsk, twenty-eight persons in Vinnytsya, twenty-six in Simferopol in the Crimea, sixteen people in Luhansk regions, fourteen people in Odessa, etc. The other sixty-one Czechs originally from Ukraine were shot in other places of the Soviet Union. Among the executed, there were ten women. An overview of the time of execution shows the importance of the period of the Great Purge in the history of political repression. Leaving aside the bloody origins of the Soviet State, for which we do not have enough sources, we can conclude that in the 1920s and in the first half of the 1930s, there only were individuals among the executed Czechs and in some years we found absolutely no executions. A turning point occurred in the years of the Great Purge 1937-1938, when a total of 533 people, i.e. $89 \%$ of all executed, were shot dead. In 1939, only five persons were shot, in 1940, a total of forty-five people (most of them were Polish prisoners from the region of Silesian Cieszyn who were shot during the Katyn massacre), and in 1941 a total of sixty-three people, mostly political prisoners, who the authorities refused to evacuate from prisons in Ukraine before the German attack. ${ }^{32}$

\section{Examples of Repressive Action Against the Czech Minority}

To select at least a few examples of repressive operations, aimed at the Czech minority at the time of the Great Purge is by no means an easy task, as each of the needlessly lost lives would surely deserved dignified remembrance. In addition, we know only basic information about the fate of most of the victims, while for the account of the context, more extensive archival study is needed.

This fully applied to the victims from the Kiev Oblast, especially from Kiev itself, which from the mid-1930s constituted the centre of the entire country, which was especially reflected in the specificity of political repression. An extraordinarily active oblast "troika" of the NKVD ordered the shooting of at least twelve and a half thousand people within sixteen months, and another more than seven thousand victims were debited to the Central "dvoika", the Commission of the NKVD and the Prosecutor of the USSR. The dead were buried secretly

32 Data on the number and structure of the victims see BORÁK, Zatajené popravy, 259-260. 
at the Lukyanivka cemetery but since spring 1937, the very probably greatest burial site of victims of political repression in Ukraine was established in the woods near the village of Bykivnia in the eastern outskirts of Kiev. So far, the numbers of victims that were buried in mass graves are still contested, however, about thirty thousand of the victims have already been identified by name. There is also at least fifty-four of the Czechs from Kiev and surrounding communities. After the war, four investigative commissions operated in Bykivnia, however the first three were tasked to prove that the dead were killed by the German occupiers during the war, as the Soviet authorities maintained to the world about crimes in Katyn, or in Vinnytsya. Even though the Soviet regime managed to remove most of the evidence from the graves, the truth about the actual perpetrators of the crime was finally proven after its fall and a National Historical Memorial to the victims of totalitarianism was built on the site in the years 1937-1941. The high stone walls that cut through the woods around the Memorial also bear the names of the murdered Czechs. ${ }^{33}$

The most famous centre of Czech colonization in eastern Podolia was the village Mykolaivka in the Koziatyn district, situated not far from the centre of the Vinnytsya Oblast. The case of the shooting of ten local Czechs has already been described by Ukrainian historians who mean that we have material to build on. ${ }^{34}$ The Czechs proved to be good farmers and craftsmen and they soon belonged to the affluent residents who the new regime began to regard as enemies. The forced collectivization meant "dekulakization", i.e. seizure of property and displacement, for them too, and the first twelve Czech families were sent to Siberia. "Offenses" from the times of collectivization could later trigger new state repression when events of the Great Purge were in order. For example the farmer Alois Černouz, regarded by many residents as a conscientious bailiff, finally entered the cooperative but was not satisfied with the organisation of work or the earnings, he regretfully remembered the old times and was friendly with the kulaks and in time of the famine, he secretly handground grain on quern-stones, which is why he was expelled from the cooperative in 1933 and earned his living as a labourer. The UNKVD "troika" of the Vinnytsia Oblast reviewed his past as counter-revolutionary and in October 1937, they sent him to eight years in the Gulag in the Magadan Oblast where he died after two months. ${ }^{35}$

At that time, Mykolaivka already had its first Czech who was executed due to political reasons. His case in a way foreshadowed the subsequent tragic events. He was a local native who after many years returned home from the Gulag, unfortunately just at the time when such returnees, ex-kulaks and anti-Soviet elements were to become the target of the first of the mass campaigns of the Great Purge. Jan Štolc was a graduate of the agricultural school and earned his living as a farmer in the Lenina collective. He was the son of a kulak and he also had relatives in Czechoslovakia which meant that it was easy to send him to the Gulag for seven years as a spy. In February 1937 he was conditionally released, but remained free for only a few months. The new indictment alleged: "Because he was

33 BORÁK, Zatajené popravy, 159-168.

34 For example SERHIY Kalytko, L.: Hirka dolja podilskych čechiv, in: Reabilitovani istorijeju. Vinnycka oblast, 1, Vinnycja 2006, 831-838; VASYLEV, Valerij J.: Pryčyny ta mechanizmy zdijsnennja masovych polityčnych represij na terytoriji Vinnyckoji oblasti v 20-30 rr, in: Polityčni represiji na Podilli, 9-23; LANOVYK, Larysa J.: Pradidiv rozčyščeni džerela, Vinnycja 2004, 21-22.

35 SERHIY, 835-836. 
dissatisfied with the Socialist establishment he started to conduct counter-revolutionary anti-Soviet campaigning of insurgent and diversionary nature, he expressed sorrow for the shot Trotskyists Kameniev et al., slandered the Spanish Revolution, discredited the collectives, and he also formed groups of kulak ements around himself." He categorically refused to plead guilty, nevertheless, based on the decision of the UNKVD "troika" of Vinnytsya Oblast, he was shot dead in August 1937. ${ }^{36}$

More executions of citizens of Mykolaivka occurred at the time when mass repressive operation of the NKVD were nearing their end but it was necessary to fulfil the increased limits on persons to be shot, as the Vinnytsya Oblast administration of the NKVD had asked for them. This led to a paradoxical situation: while the executions were waning in Moscow in October 1938 (the last Czechoslovak citizen was shot dead on 10 September 1938), they were still in full swing in Vinnytsya. This made ten Czechs from Mykolaivka pay the fatal price. Just as the case of Jan Štolc served the Vinnytsya Oblast leadership of the NKVD at the very beginning of the purge activities (they discussed it at the second meeting of the Oblast troika), so too it became good inspiration for the authorities of the NKVD a year later when the purge was slowly waning. They only needed to collect those "kulak elements from the village" and to match them with suitable roles in the rebel organization. It was not too difficult: for example, Štolc's brother Joseph was also a returnee from the Gulag. All Czech activities, from the oldest of the first world war, when the local Czechs supported the Czechoslovak Legion in Ukraine and held collections to support them, to those from the 1920s, when there were Czech organisations - the Association of Cultural Czech Landlords (1924-1928), which secured foreign technology for the colonists, or the Czech Cooperative (in the years 1928-1930) which sold farm machinery, mostly from Czechoslovakia, could be appropriately used as evidence of counter-revolution or espionage. Also, communications with the known organizer of Czech activities, Antonín Vodsedálek, teacher of Czech literature at the Pedagogical Institute in Zhytomyr and to the authorities of the NKVD, a major resident of the spy network, were mentioned. Thus it was easy to fabricate a Czech spy agency and it was just as easy to make up a guerrilla organization as well which in the case of a war was to blow up the steam depot on the railway station Kozjatyn. Vladimir Va irovský was selected as the boss of the whole organization and a collective investigation file was opened on all of the ten accused. ${ }^{37}$ In the end, however, the charges of spying for the Czechoslovak intelligence were changed hastily to espionage for Germany. This was because the UNKVD "troika" of Vinnytsya only had a meeting later, in early October 1938, when the Soviet Union was posing as the protector of Czechoslovakia against German aggression against Czechoslovakia and the investigators found it more appropriate to charge the Czechs of working for Germany. Once they had forced them to change testimony, they shot them as agents of German intelligence. ${ }^{38}$

\section{LANOVYK, 22.}

37 SERHIY, 835-837; Deržavnyj archiv Vinnyckoji oblasti [The State Archive of the Vinnytsya Oblast, hereinafter referred to as DAVO], f. P-6023, op. 5, spr. 135852.

38 LOŠYCKYJ, O.: "Laboratorija". Novi dokumenty i svidčennja pro masovi represiji 1937-1938 rokiv na Vinnyčyni, in: Z archiviv VUČK-GPU-NKVD-KGB, 1998, 1/2, 213-214. The testimony of A. J. Levinzon from August 11, 1939. 
The most repressive action against the Czechs in Ukraine took place in Zhytomyr where on a single day, 28 September 1938, eighty alleged conspirators were shot dead, including seventy-eight Czechs. The event has been discussed several times by the Ukrainian historians ${ }^{39}$ and it has recently been elaborated in Czech. ${ }^{40}$ It can serve us as an example to characterize the repression of the Great Purge which many other Czechs in Ukraine were subject to whose fate unfortunately cannot be remembered in this cursory overview.

The Zhytomyr case was connected with the tampering of evidence on the subversive activities of the wide-ranging "Czech military-insurgent espionage organization". The investigation was led by the $3^{\text {rd }}$ Department of State Security of the NKVD for the Zhytomyr Oblast, the arrests took place from February to August 1938 not only in Zhytomyr and the surrounding area, mainly in the Czech Kroshna, but also in the Czech centres in the Zhytomyr Oblast districts Andrushivsk, Korostyshivsk, Chernyakhovsk, Malynsk and Chervonoarmysk Chervonoarmiysk. ${ }^{41}$ Looking at the social structure of those arrested, it is evident that representatives of Czech intelligence are almost missing among them as they had been subjected to political repression among the first ones at the beginning of the Great Purge. The accused included forty-two collective farm workers, twelve workers of different businesses, five locksmiths, three accountants, three joiners, two drivers, a postman, a shoemaker, a carpenter, a teacher and several staff of various institutions. The action was drawn up on 26 July 1938 with the proposal that it be referred to "discussion by the NKVD USSR within command no. 00485". The document was signed by the chief of service of the unit of III. dpt. of the UGB UNKVD, Sergeant of State Security Maňko and consent was also given by the chief of the III. dpt. UGB UNKVD Lieutenant of State Security Fedorov. ${ }^{42}$

All charges were eventually included in the collective investigation file which was due to its sheer size divided into seven volumes. ${ }^{43}$ The final dossier of the action took on the form of a slim booklet and is reminiscent of the "master" action in Kharkov process with the intelligence service of "the Czech General Staff" from 1931. The new Czech treasonous organization was devised under the name of "Czech cooperative", loosely translated as "the Czech nationalist insurgent association". The origins of this organization went back

39 ŠEVČUK, 223-237; LUCKIJ, Jurij: Česki spravy (1930-1937 rr.), in: Z archiviv VUČK-GPU-NKVD-KGB, 1999, 1/2 (10-11), 156-168; LUCKIJ, Jurij - LUTAJ, Majja: Polityčni represiji ščodo českoho naselenija Žytomyrščyny (1920-1950-i rr.), in: Chronika-2000, Ukrajinskyj kulturologičnyj almanac, 8, 29-30, Ukrajina-Čechija, 2, Kiev 1999, 139-145; LUTAJ, Majja: Čechy na Žytomyrščyni. Istorija i sohodennja, Zhytomyr 2008; Trahični storinky istoriji Žytomyrščyny 1917-1980-ch rokiv, in: Reabilitovani istorijeju. Žytomyrska oblast, 1, Zhytomyr 2006, 38-39; KOPIJČENKO, Larysa A.: Represiji sered českoho naselennja Žytomyrščyny, in: Reabilitovani istorijeju. Žytomyrska oblast, 2, Zhytomyr 2008, 7-18.

40 BORÁK, Mečislav: Popravy jako součást politických represí v SSSR a dosud zjištěné oběti z řad Čechů a československých občanů [Executions as Part of Political Repression in the USSR and the Currently Known Victims from Among the Czechs and the Czechoslovak Citizens], in: Perzekuce československých občanů v Sovětském svazu (1918-1956). Část I. - Vězni a popravení [Persecution of Czechoslovak Citizens in the Soviet Union (19181956). Part I - Prisoners and Executed], BORÁK, Mečislav (Ed.), Opava 2007, 176-177; BORÁK, Zatajené popravy, 83-148.

41 LUTAJ, Trahični storinky istoriji, 39; LUCKIJ - LUTAJ, 139-145.

42 ŠEVČUK, 232; LUTAJ, 19.

43 Deržavnyj archiv Žytomyrskoji oblasti [The State Archive of the Zhytomyr Oblast, hereinafter referred to as DAŽO], f. 5013, op. 2, spr. 7060-P, t. 1-7 (2917-2923). 
to 1919 when two Czech prisoners of war came to Volhynia from the Volga region and founded a Sokol gymnastic organization. Under its guise, they then conducted "counterrevolutionary nationalist organizational activity" in the Czech population of Volhynia. In the second half of the twenties, this sabotage activity was allegedly organized by local personalities of the Czech minority, the commander of the Zhytomyr firing division Jaroslav Štrombach and the principal of the Czech school Antonín Vodsed'álek who allegedly founded the "Czech military-rebel company" in the individual colonies in the Oblast, in businesses and in Czech schools, which were facaded as "branches" of the Sokol movement. From this network then stemmed a separate Czech military-rebel organization with the code name "Czech cooperative". Fabricating this fictional organization, the investigators apparently remembered the case of the organizers of the "Cooperative" from 1928 and were inspired by the "master" Czech process from 1931. Although they had pulled out from it its former protagonists as the founders and initiators of the new organization, they could not take advantage of them in present, as Štrombach had been executed in 1931 and Vodsedálek was serving a Gulag sentence on Solovetsky Islands. Thus, they fabricated a new leadership to the organization, in time of the Great Purge which consisted of the carpenter Stěpán Toman from Czech Kroshnya, the chief accountant and planner of the Zhytomyr brewery Josef Jandura, and the inspector of Zhytomyr city financial office, Václav Holan, a renowned orchardist. ${ }^{44}$

All three members of the leadership of the fictional conspiracy organization promptly refused any accusation of anti-Soviet activities as there was nothing to confess. According to the protocols in their investigation files, each of them was interrogated only twice but in fact, they were forced to confess until they confirmed the investigators' construction. Jandura resisted about a month long, Holan fifty-three days and Toman even eighty days. He repeated over and over: "I do not belong to any counter-revolutionary organization and I have never performed any activity against the USSR in favour of any foreign country." However, even he eventually succumbed and like the others, he admitted to anti-Soviet activity. ${ }^{45}$ Not long after the repression of the Great Purge, it became clear that the investigators in Zhytomyr commonly used illegal methods of interrogation to force confessions from the accused. The interrogation protocols were often made in advance, the conclusions of the accusations were copied from a template, and the accused were forced to sign by all sorts of threats and extortion, including the use of gross physical violence and cruel torture which were in completely regular occurrence at the time of the Great Purge. ${ }^{46}$

The investigators also adopted from past cases main methods of subversion of the accused, i.e. their relations with Czechoslovakia and the espionage residence at the Czechoslovak Consulate in Kiev. For example, resident Josef Vlasák was coming to Ukraine through the travel agency Intourist in the years 1936-1937 to develop Czech counter-revolutionary activity, and F. Jandura was in connection with the Secretary of the Czech Consulate in Kiev

44 DAŽO, Ibidem, t. 4 (2920), Obvinitělnoje zaključenije po dělu češskoj vojenno-povstančeskoj organizacii. Zhytomyr, UGB-UNKVD po Žitomirskoj oblasti 1938 [62 vol.], p. 1-3; KOPIJČENKO, 18; LUTAJ, Trahični storinky istoriji, 38; BORÁK, Zatajené popravy, 111-123.

45 KOPIJČENKO, 14.

46 BORÁK, Zatajené popravy, 85. 
from whom he received orders "for practical counter-revolutionary activities". Although these were not specified anywhere, the dossier assumed that the companies created were responsible for the "grouping of Czech rebel cadres, their preparation for armed rebellion at the time of intervention on the part of Germany, and the performance of intelligence work on the territory of the USSR for the interest of the Czechoslovak intelligence". Not much concrete evidence was needed for the out-of-court "troika" trials; the final summary of the case fabricated and produced directly in the Zhytomyr Oblast Administration Office of the NKVD was completely sufficient: "The investigation of this case detected and destroyed four rebel suites and twelve 'branches'." 47

The file also contains the list of the eighty accused whose guilt was usually characterized in the form of a few lines of typical phrases of the period. The absurdity of some of the accusations was obvious at first glance, but enough to earn a death sentence. For example, Antonín Borůvka "carried out activities aimed at the destruction of the horses of the kolkhoz", František Bureš was undermining the kolkhoz's work ethic and he "intentionally left a large amount of the kolkhoz's potatoes to rot", Vladimir Fortelka, "as the bookkeeper of the kolkhoz kept the books negligently and reduced the payments to work units, causing dissatisfaction among the kolkhozists", Alexandr Hřeblík spread gossip about war among the villagers and "cultivated the kolkhoz land poorly", Antonín Kocián "showed emigration tendency and more than once tried to obtain Czechoslovak citizenship with a subsequent permit of departure abroad", Franti ek Novotný "used the work of a mail clerk for counter-revolutionary purposes, often deliberately confusing mail deliveries and holding them back for a long time; he also left people standing in the queue for long times, and there were even cases where he sent the received mail back." ${ }^{48}$

The accused did not have a chance to escape the death penalty. The quest for the fulfilment of the specified limit of sentences in the "first category", i.e. the people intended to be shot dead, led the Zhytomyr Oblast NKVD "troika" in the time from April to May 1938 when headed by chief Grigory Viatkin not to give a single sentence of imprisonment in the Gulag and all of the 1,999 convicts were shot dead. ${ }^{49}$ For the next few months, meetings of the Oblast NKVD "troika" were not held at all and new cases were not forwarded to other institutions as the investigators apparently understood that the documents gathered by the prosecution probably would not stand in the out-of-court proceedings of the "dvoika" or of the Military College of the Supreme Court. In mid-September 1938, an order came from the Moscow NKVD headquarters, pre-approved by the Politburo of the Central Committee of the All-Union Communist Party ordering to finish the yet undecided cases of the counter-revolutionary nationalist "contingents" using "special troikas". Such a "troika" was founded in Zhytomyr, consisting of the Chief of NKVD Oblast Administration Viatkin, the Oblast Secretary of the Communist Party of Ukraine Maxim A. Didenko and the Zhytomyr Oblast Prosecutor Vasil D. Rosputko. Over just a month and a half of its existence, this "special troika" had 4,165 people shot dead with only thirty-eight of the sentenced being sent to the Gulag. "Czech cooperative" was discussed already at its third

47 KOPIJČENKO, 4.

48 BORÁK, Zatajené popravy, 114-119.

49 LUTAJ, Trahični storinky istoriji, 31. 
session on 22 September 1938 when 408 people were sentenced and no other sentence than the death penalty was issued..$^{50}$

The sentence was enforced, i.e. all of the eighty convicts were shot dead, on 28 September 1938 - by an extraordinary accident exactly on the feast day of St. Wenceslas, the Czech patron saint, to whose memory the Catholic Church in Czech Kroshna was consecrated. Similarly mixed emotions arise also from the strange timing of this largest mass execution of Czechs in the Soviet Union in the days when negotiations on the fate of Czechoslovakia, whom the Soviet Union offered its assistance, were in preparation in Munich. At that time, however, no one knew about this crime and even the relatives of victims discovered the truth after many decades, mostly in the 1990s.

Security staff were bound by strict secrecy and the families of victims received from the authorities the stereotypical answers that their loved ones were taken for ten years in labour camps and do not have the right to correspondence. Some families, however, did not intend to accept the disappearance of their loved ones and filed complaints about the course of the criminal proceedings, believing that they can achieve their release from the Gulag. One of the first complaints was by the family of Vladimír Pilař, assigned to the prosecutor of the Investigation Department of the Zhytomyr Oblast Prosecutor's Office Bychkov. In the conclusions of his investigation on 1 August, 1940, he stated that he had studied the materials on the activities of the Czech military-rebel spy organization "Czech cooperative" and concluded that it was detected and disposed of in accordance with the law as the guilt of the convicts had been demonstrated sufficiently. ${ }^{51}$

However, it had already been known for over a year at that time that the case of the "Czech cooperative" and dozens of others have been fabricated from start to finish by investigators and some of them had even been executed. The Chief of the NKVD Oblast Administration Viatkin, who bore primary responsibility for the extraordinary extent of last phase of the Great Purge in Zhytomyr in September and October 1938 was relieved of his duties even a few days before the issuance of an official order to stop their mass repressive activities. Ironically, he was arrested not for abuse of power and falsification of thousands of investigation files, but for alleged counter-revolutionary activities, which he allegedly carried out as a member of a "right-wing Trotskyist" organization. He later testified that the protocols of "troika" trials were in many cases formulated after the sentence had been carried out and that the cases were not addressed at the meetings. Thus, cases routinely occurred where people whose guilt had not been established by the "troika" were shot dead, and their names were only added to the protocols subsequently. In February 1939, Viatkin was sentenced to death and executed. His colleagues - the party's secretary Didenko and the prosecutor Rosputko - escaped only with penalties of eight and four years in the Gulag, respectively. ${ }^{52}$

Investigations from the years 1939-1940 proved that the abuse of official powers and "missteps" were not only taken by the Oblast chiefs Yakushev and Viatkin but also by many of their collaborators. For example, Mikhail J. Fedorov, Chief of $3^{\text {rd }}$ State Security

50 Ibidem, 35.

51 DAŽO, f. 5013, op. 2, spr. 7060-P, t. 4 (2920), p. 63-70.

52 RAFALSKA, 153-155. 
Department of the UNKVD administration in Zhytomyr was arresting suspects in the framework of the nationalist operations completely without evidence, based on fictitious charges only. He required of his subordinates to obtain at least five confessions a day which could only be enforced by beatings. He also retroactively let the "troika" confirm death sentences of people beaten to death during interrogation. His deputy Danylo I. Maňko was setting up false accusations with fabricated details of treasonous activities, ordered beatings and torture during interrogation, as the rapporteur of the "troika" meetings, he championed the recognition of completely fabricated group cases and formulated the "troika" statements. Matvei E. Lesnov-Izrailev, Chief of $4^{\text {th }}$ State Security Department of the UNKVD administration also led the interrogations by illegal methods, signing the charges without the knowledge of the files and forwarding them to the "troika", so several persons who had not been charged at all were shot dead. Danylo J. Maluka, Chief of Division at the $4^{\text {th }}$ Department of UGB UNKVD, heavily beat the interrogated on a regular basis and forced his subordinates to do the same. Mitrofan S. Liulkov, one of the commanders of the Oblast administration, also took part in the beatings and torture of the interrogated on a regular basis. Nikolai A. Zub, Chief of the $1^{\text {st }}$ Special Department of the UNKVD wrote the protocols of the meetings of the "troika", changing transcriptions of names and other information which allowed for additional entries of those beaten to death. The first four of these commanders were sentenced to death by the Military Tribunal of the NKVD Troops of the Kiev Military District in 1940 and executed, the last two were sentences to imprisonment in the Gulag. ${ }^{53}$

The results of the investigation were kept strictly secret for many years and the families of victims could only seek justice after the partial easing of political circumstances in the USSR the second half of the 1950s. In September 1957, the case of the Czech cooperative was re-examined as well. ${ }^{54}$ The conclusions of this long revision were congruent with the facts established already in 1939. They stated for example: "The Germans, Poles, Czechs, and persons of other nationalities were subjected to arrests without any existing facts about their criminal activities. [...] For every person, a fictional report was compiled which stated that the person concerned is a member of the Polish, Czech, German or other anti-Soviet organization and carries out counter-revolutionary activities. On the basis of such fictitious reports, the prosecutor consented with the arrest. [...] The management of the NKVD Administration and the Department argued that, if the arrested German, Czech, Latvian or Polish, they need to answer as to belonging to the counter-revolutionary underground." The Chief of the Oblast Administration claimed in meetings that workers, whose arrestees do not provide testimony leading to a confession, arouse suspicion themselves. This is why fictional interrogation protocols were made and false confessions were forced by means of promises and threats, beatings and cruel torture..$^{55}$

The new investigation was closed by filing a protest of the military prosecutor to the Military Tribunal of the Carpathian Military District which at its meeting of 30 June, 1958 annulled the decisions of the Zhytomyr Oblast UNKVD "troika" and set the proceedings aside for

53 DAŽO, f. 5013, op. 2, spr. 7060-P, t. 5 (2921). Materialy proverki po dělu № 15948. Obzornaja spravka po arch.-sl. dělu № 18842 .

54 Ibidem, Letter of Col. Bogomaza of 9 July 1957.

55 Ibidem, Matěrialy proverki po dělu № 15948. 
the lack of facts of cases. ${ }^{56}$ Now, the authorities were able to answer the questions of the victims' relatives about the fate of their loved ones, stating that they all have already been rehabilitated which had a significant impact on restoring the social status of the victims' families. At the same time for the first time, they acknowledged their death. Indeed, it would be difficult to justify why they had not come back from the Gulag camps when the ten years of the alleged penalty had long since passed. A strict ban on any mention of death sentences and executions, however, continued to apply, so that the authorities of the KGB, the successor of the former NKVD, kept on falsifying documents. The aim was to convince the victim's relatives that their loved ones were actually sent to labour camps, where, however, they unfortunately died of normal diseases after a few years. As registrar offices were also under the supervision of the Ministry of the Interior, forging death certificates and false entries into the registry was relatively easy, even if there were hundreds of thousands of cases all over the whole country. It was only in the 1960s that communicating the true dates of death was allowed, but not the true cause. The truth about executions first began to be imparted in the late 1980s under Gorbachev's "perestroika", that is up to half a century after they had taken place. Information about the place of death was not learned by the victims' relatives until the 1990s, while in many cases, the place of burial of their bodies remains unknown to this day. Only the systematic, long-term lying by the authorities can explain why many of the relatives of the victims had fallen for lies and believe to this day that their loved ones died during the war or shortly after somewhere in a Siberian Gulag and have no idea that their remains have, in fact, been buried already in the late 1930 s in the outskirts of the very city they lived in. ${ }^{57}$

By finding the specific names of the victims of repression and the circumstances of their deaths, the hitherto research has only taken the first important step. The lists of victims are not yet final, the publication of new lists has due to the eventful political landscape of late been delayed, so that even some of the major cities (e.g. Kiev and Kharkov) still do not have such overview. This, of course, even more significantly concerns other parts of Ukraine as well. Therefore, we may reasonably assume that once the lists of victims of political repression are updated, the number of Czechs executed by in the time of the Great Purge is likely to increase, perhaps even by a hundred other names. But even as regards those already identified, we are still left with the task of substantially supplementing their life stories, pulling the details about their lost struggles for life out of the archives, and sometimes even naming the criminals who partook in their death. The Ukrainian archives' friendly approach and their door set ajar, especially those of the state security archives, could provide good incentive for young researchers from the Czech Republic who would like to take on such a challenge.

56 Ibidem, Opredělenije № Ož-638.

57 BORÁK, Zatajené popravy, 126-127. 


\section{References}

Deržavnyj archiv Žytomyrskoji oblasti (DAŽO)

The State Archive of the Zhytomyr Oblast

f. 5013

Deržavnyj archiv Vinnyckoji oblasti (DAVO)

The State Archive of the Vinnytsya Oblast

f. P-6023

Haluzevyj deržavnyj Archive Services bezpeky Ukraine (HDA SBU) Departmental State Archive of the Security Service of Ukraine

f. 6 .

BORÁK, Mečislav: České stopy v Gulagu. Z výzkumu perzekuce Čechů a občanů ČR $\checkmark$ Sovětském svazu [Tracing Czechs in the Gulag. From the Research on the Persecution of Czechoslovak Citizens in the Soviet Union], Opava 2003.

BORÁK, Mečislav: Popravy jako součást politických represí v SSSR a dosud zjištěné oběti z řad Čechů a československých občanů [Executions as Part of Political Repression in the USSR and the Currently Known Victims from Among the Czechs and the Czechoslovak Citizens], in: Perzekuce československých občanů v Sovětském svazu (1918-1956). Část I. - Vězni a popravení [Persecution of Czechoslovak Citizens in the Soviet Union (19181956). Part I - Prisoners and Executed], BORÁK, Mečislav (Ed.), Opava 2007.

BORÁK, Mečislav: Zatajené popravy. Češi a českoslovenští občané popravení na sovětské Ukrajině: z historie Velkého teroru na Volyni a v Podolí. [Secret Executions. The Czechs and the Czechoslovak Citizens Executed in the Soviet Ukraine: a History of the Great Purge in Volhynia and Podolia], Opava 2014.

DVOŘÁK, Jan: Antonín Vodsedálek a proces s českými učiteli na Ukrajině [Antonín Vodsed'álek and the Process with Czech Teachers in Ukraine], in: Pamět' a dějiny, Revue pro studium totalitních režimů [Memory and history. Revue for the Study of Totalitarian Regimes], 7, 2013, 4, 97-108.

HOSTIČKA, Vladimír: Volyňští Češi a jejich perzekuce v SSSR [Volhynian Czechs and their persecution in the Soviet Union], in: Střední a východní Evropa v krizi XX. století [Central and Eastern Europe in the crisis of the twentieth century], Prague 1998, 47-60.

KOPIJČENKO, Larysa A.: Represiji sered českoho naselennja Žytomyrščyny, in: Reabilitovani istorijeju. Žytomyrska oblast, 2, Zhytomyr 2008, 4, 7-18.

LANOVYK, Larysa J.: Pradidiv rozčyščeni džerela, Vinnycja 2004.

LOŠYCKYJ, O.: "Laboratorija". Novi dokumenty i svidčennja pro masovi represiji 19371938 rokiv na Vinnyčyni, in: Z archiviv VUČK-GPU-NKVD-KGB, 1998, 1/2, 213-214.

LUCKIJ, Jurij: Česki spravy (1930-1937 rr.), in: Z archiviv VUČK-GPU-NKVD-KGB, 1999, 1/2 (10-11), 156-168

LUCKIJ, Jurij - LUTAJ, Majja: Polityčni represiji ščodo českoho naselenija Žytomyrščyny (1920-1950-i rr.), in: Chronika-2000, Ukrajinskyj kulturologičnyj almanac, 8, 29-30, Ukrajina-Čechija, 2, Kiev 1999, 139-145.

LUTAJ, Majja: Trahični storinky istoriji Žytomyrščyny 1917-1980-ch rokiv, in: Reabilitovani istorijeju. Žytomyrska oblast, 1, Zhytomyr 2006.

LUTAJ, Majja: Čechy na Žytomyrščyni. Istorija i sohodennja, Zhytomyr 2008. 
MOZOCHIN, Oleg B.: Pravo na represssii. Vněsuděbnyje polnomočija organov gosudarstvennoj bezopasnosti. Statističeskije sveděnija o dějatělnosti VČK-OGPUNKVD-MGB SSSR (1918-1953), 2-e izd, Moscow 2011, 191-192.

PODKUR, Roman: "Velykyj teror" na Vinnyččyni (1937-1938 rr.): dijalnist' terytorialnogo aparatu organiv deržavnoji bezpeky, stereotypy svitogljadu čekistiv, in: Zločyny totalitarnych režimiv v Ukrajini: naukovyj ta osvitnij pogljad, Kiev 2012, 61-63.

Polityčni represiji na Vinnyččyni. 1918-1980-ti roky, in: Reabilitovani istorijeju. Vinnycka oblast, 1, Vinnycja 2006.

RAFALSKA, Tetjana L.: "Velykyj teror" na Žytomyrščyni (lipec 1937 r. - listopad 1938 r.), Disertacija, Kiev, Nacionalnyj pedagogičnyj universytet M. P, Dragomanova 2010.

SERHIY Kalytko, L.: Hirka dolja podilskych čechiv, in: Reabilitovani istorijeju. Vinnycka oblast, 1, Vinnycja 2006, 831-838.

ŠAPOVAL, Yuri I.: "Ukrainskije nacionalisty" v ramkach prikaza na primere Kijevskoj oblasti, in: Stalinizm v sovetskoj provincii. 1937-1938 gg. Massovaja operacija na osnove prikaza, 00447, Moscow 2009, 392-393.

ŠAPOVAL, Yuri I. - PRYSTAJKO, Volodymyr I. - ZOLOTAROV, Vadym A.: ČK-DPU-NKVS na Ukrajini. Osoby, fakty, dokumenty, Kiev 1997.

ŠEDIVÝ, Ivan: Sdružení Čechů a Slováků z Ruska a československá vláda 1919-1929 (Podpory, subvence, dotace, odškodnění) [Association of Czechs and Slovaks from Russia and the Czechoslovak Government 1919-1929 (Aids, Grants, Subsidies, Compensation)], in: Československý časopis historický [Czechoslovak Historical Magazine], 36, 1988, 2, 212-237.

ŠEVČUK, Jurij: Polityčni represiji proty českoji intelihenciji Žytomyrščyny v dobu "Velykoho teroru", in: Istoryko-heohrafični doslidžennja v Ukrajini, Instytut istoriji Ukraine 2009.

URBAN, Rudolf: Na Sibiřr? Zkušenosti českých osadníků v zemi sovětů [To Siberia? Experience of Czech Settlers in the Land of the Soviets], Prague 1943.

VACULíK, Jaroslav: Dějiny volyňských Čechů Díl II. (1914-1945) [History of Volhynian Czechs Part II. (1914-1945)], Prague 1998.

VACULÍK, Jaroslav: České menšiny v Evropě a ve světě [Czech Minorities in Europe and in the World], Prague 2009.

VALÁŠKOVÁ, Nad'a: Češi v Rusku [Czechs in Russia], in: Češi v cizině [Czechs Abroad], 9, 1996, 26-47.

VASYLEV, Valerij J.: Pryčyny ta mechanizmy zdijsnennja masovych polityčnych represij na terytoriji Vinnyckoji oblasti v 20-30 rr, in: Polityčni represiji na Podilli, 9-23.

Velykyj teror na Ukrajini. "Kurkulskaja operacija" 1937-1938 rr. Častyna II., KOKIN, Sergij - JUNGE, Mark (Ed.), Kiev 2010.

\section{Author}

prof. PhDr. Mečislav Borák, CSc.

Ústav pro studium totalitních režimů

The Institute for the Study of Totalitarian Regimes

Siwiecova 2, 13000 Praha 3, The Czech Republic

cep@fvp.slu.cz 